Reconfiguring Chinese Nationalism 



\title{
Reconfiguring Chinese Nationalism
}

\author{
How the Qing Frontier and its \\ Indigenes Became Chinese
}

James Leibold 
Softcover reprint of the hardcover 1st edition 2007 978-1-4039-7479-2

All rights reserved. No part of this book may be used or reproduced in any manner whatsoever without written permission except in the case of brief quotations embodied in critical articles or reviews.

First published in 2007 by

PALGRAVE MACMILLAN ${ }^{\text {TM }}$

175 Fifth Avenue, New York, N.Y. 10010 and

Houndmills, Basingstoke, Hampshire, England RG21 6XS.

Companies and representatives throughout the world.

PALGRAVE MACMILLAN is the global academic imprint of the Palgrave Macmillan division of St. Martin's Press, LLC and of Palgrave Macmillan Ltd. Macmillan ${ }^{\circledR}$ is a registered trademark in the United States, United Kingdom and other countries. Palgrave is a registered trademark in the European Union and other countries.

ISBN 978-1-349-73733-8

ISBN 978-1-137-09884-9 (eBook)

DOI 10.1007/978-1-137-09884-9

Library of Congress Cataloging-in-Publication Data is available from the Library of Congress.

A catalogue record of the book is available from the British Library.

Design by Scribe, Inc.

First edition: December 2007

10987654321

Transferred to Digital Printing in 2009 
To my parents, Frank and Danielle Leibold 



\section{Contents}

Acknowledgments $\quad$ ix

Introduction $\quad 1$

1 From Empire to Nation:

$\begin{array}{ll}\text { The Bounding of the Chinese Geo-body } & 17\end{array}$

\section{Part I: Strategies of Political Intervention}

2 Borderlands of State Power:

The Nationalists and the Frontier Question $\quad 51$

3 Domesticating Minzu:

The Communists and the National Question $\quad 81$

\section{Part II: Narratives of Cultural Innovation}

4 From the Yellow Emperor to Peking Man:

The Nationalists and the Construction of Zhonghua minzu 113

5 Han Man's Burden:

The Communists and the Construction of Zhonghua minzu 147

$\begin{array}{ll}\text { Conclusion } & 177\end{array}$

$\begin{array}{ll}\text { Notes } & 185\end{array}$

References 219

Index 255 



\section{Acknowledgments}

This book is the culmination of a long and often circuitous process-one that would not have been possible without the assistance and support of many. It began some ten years ago as a doctoral dissertation at the University of Southern California under the mentorship and steady guidance of Charlotte Furth. I would like to thank Charlotte and the other members of my committee, John Wills Jr., Eugene Cooper, and Michael Robinson, for their thoughtful suggestions, comments, and encouragement throughout my time in Los Angeles.

The current manuscript evolved during my time at the University of Melbourne and La Trobe University in Australia. I would like to thank all my colleagues at both universities for their support, stimulation, and words of reassurance. I consider myself lucky to have landed in Melbourne, where its pleasant environs and active, internationally-engaged Chinese studies community have provided an ideal setting in which to live, work, and raise a family. I would like to especially thank John Fitzgerald and Antonia Finnane for their assistance, friendship, and encouragement since arriving in Australia in 2000.

Chen Zhihong, Alice Falk, John Fitzgerald, Hon Tze-ki, and Laurence Schneider read the entire manuscript while another anonymous reviewer read several chapters in draft form. Tom Mullaney, Brian Moloughney, and Jeff KyongMcClain read and offered their comments on several final chapters. Together they provided thoughtful and constructive comments that significantly improved the final version.

Numerous others have either commented on previous versions of my work or offered helpful suggestions, citations, resources, or critical insights along the way: Joseph Allen, Dennis Altman, Stefan Auer, Thomas Bartlett, Alan Baumler, David Bello, Gordon Berger, Kathryn Bernhardt, Anya Bernstein, David Bradley, Judith Brett, Clayton D. Brown, Rob Culp, Thomas DuBois, Arianne Gaetano, Hua Tao, Gerhard Hoffstaedter, Huang Jianli, James Huffman, Bruce Jacobs, Robin Jeffrey, Joel Kahn, William Kirby, P. T. Lee, Li Liangyu, Jonathan Lipman, Liu Xiaoyuan, Raymond Lum, Colin Mackerras, Robert Manne, Angus McIntyre, Jenny McGregor, Anne McLaren, Stanley Mickel, Charlie Musgrove, Kaori Okano, Raj Pandey, Qin Can, Merle Ricklefs, Eugene Swanger, Justin Tighe, Saul Thomas, Isenbike Togan, Paul Van Dyke, Geoff Wade, Wang Dong, 
Wang Gungwu, Wang Xi, Trevor Wilson, and Yang Zhenya. Collectively these individuals have helped to save me from numerous embarrassing mistakes and have helped to shape many of the ideas developed here. Needless to say, any remaining mistakes (and I am sure there are some) and final conclusions remain my own.

Librarians are often the unsung heroes of historical research, especially those involving such a rich literary tradition like China's. I would like to thank the librarians and staff at the following institutions for their assistance and infinite patience in tracking down many of the primary and secondary sources on which this book rests: the Doheny Library at the University of Southern California; Richard C. Rudolph East Asian Library, University of California, Los Angeles; C. V. Starr East Asian Library at the University of California, Berkeley; HarvardYenching Library at Harvard University; Nanjing University Library; Shanghai Municipal Library; the Nanjing Municipal Library; the Fu Ping Shan Library at Hong Kong University; the National Library of Australia; Menzies Library at the Australian National University; the East Asian Collection at Melbourne University; and finally the amazing interlibrary loan staff at Borchardt Library, La Trobe University, who helped me search the world for obscure Chinese books and journal articles during the final stages of this project.

A number of funding bodies have provided financial support for this project, including the Social Science Research Council's Abe Fellowship Program, the U.S. Department of Education's Foreign Language and Area Studies Fellowship Program, the U.S. State Department's NSEP David Boren Graduate Fellowship Program, Harvard-Yenching Library, the University of Southern California and La Trobe University. I would also like to acknowledge the helpful people at Palgrave Macmillan who guided me through the publication process, especially Alessandra Bastagli, Chris Chappell, Brigitte Shull, Emily Leithauser, Katie Fahey, and Daniel Constantino at Scribe.

Some of the material presented here was published in an earlier form. I am grateful to the publishers for allowing me to reuse portions of the following works: "Positioning 'Minzu' within Sun Yat-sen's Discourse of Minzuzhuyi," Journal of Asian History 38.2: 163-213, copyright 2004 by Harrassowitz Verlag; "Rethinking Kuomintang National Minority Policy: The National Question and Regional Warlordism on the Early 20th Century Chinese Frontier," in Cindy Yik-Yi Chu and Ricardo K.S. Mak, eds. China Reconstructs (Lanham: University Press of America), copyright 2003 by Rowman \& Littlefield Publishing Group; "Un-mapping Republican China's Tibetan Frontier: Politics, Militarism and Ethnicity along the Kham/Xikang Borderland," The Chinese Historical Review 12.2 (Fall): 167-201, copyright 2005 by The Chinese Historians in the United States, Inc.; "Competing Narratives of Racial and Unity in Republican China: From the Yellow Emperor to Peking Man," Modern China 32.2 (April): 181-220, copyright 2006 by Sage Publications.

Finally, this project would have never been conceived, sustained, or completed without the loving support, patience, and encouragement of my families on both sides of the Pacific: Frank and Danielle Leibold, Liz and John Lonergan, Debbie 
and Darryl Czuchra, and Lori and Phil Wentworth in the United States; and Don and Adrienne Axup and David and Stella Axup in Australia. And finally my own family, Kate, Bridget, and Harry, helped nurture and sustain this project through the countless hours of research, reading, writing, and rewriting. Kate Axup, in particular, got perhaps more than she bargained for when we first met in Nanjing in 1996. Footnote after footnote, library after library, and rewrite after rewrite, she has served "quietly" and confidently as my financial supporter, editor in chief, intellectual sounding board, emotional consoler, and now proud mother of three-Bridget, Harry, and Reconfiguring Chinese Nationalism.

James Leibold

Melbourne, August 2007 